\title{
Sip New Disease Reports \\ First report of tomato bacterial speck caused by Pseudomonas syringae pv. tomato in Tunisia
}

\author{
I. Mensi ${ }^{1}{ }^{*}$, H. Jabnoun-Khiareddine ${ }^{2}$, N.E. Zarrougui ${ }^{1}$, H. Ben Zahra ${ }^{1}$, S. Cesbron ${ }^{3}$, M.A. Jacques ${ }^{3}$ and M. Daami-Remadi $^{2}$ \\ ${ }^{1}$ Department of Plant Protection, Higher Agronomic Institute, Chott-Mariem, IRESA-University of Sousse, Tunisia; ${ }^{2}$ \\ UR13AGR09-Integrated Horticultural Production in the Tunisian Centre-East, Regional Research Centre on Horticulture and \\ Organic Agriculture, University of Sousse, Chott-Mariem, Tunisia; ${ }^{3}$ IRHS, INRA, AGROCAMPUS-Ouest, Université d'Angers, \\ SFR4207 QUASAV, 42, Rue Georges Morel, 49071, Beaucouzé, France
}

*E-mail: mensimen@hotmail.fr

Received: 02 Oct 2018. Published: 12 Nov 2018. Keywords: bacterial plant disease, Solanum lycopersicum

In spring 2016, severe spots were observed on nearly all tomato plants cvs. Amal, Kaouther and Malinche grown in several greenhouses in the region of Teboulba, on the eastern coast of Tunisia. Affected plants presented 1 to $5 \mathrm{~mm}$, angular, necrotic spots surrounded by a yellow halo on young and older leaves (Fig. 1). When numerous lesions occurred on a single leaflet, they coalesced and a portion or the entire leaflet turned necrotic and died. Necrotic lesions were also observed on petioles, peduncles and stems of diseased plants. In some cases, a brown-black colouration was observed along the entire stem (Fig. 2). Similar necrotic symptoms were observed during spring 2017 on tomato seedlings grown in nurseries in the Kairouan governorate, in the centre of Tunisia (Fig. 3).

Sixteen bacterial isolates were recovered from diseased plants of the three tomato cultivars and seedlings described above. Isolates were grown on tryptone casein soya agar medium and incubated at $28^{\circ} \mathrm{C}$. All isolates were Gram negative, oxidase negative, produced levan and induced a hypersensitive reaction on tobacco leaves. These isolates were not fluorescent under ultraviolet light when grown on King's B medium.

The pathogenicity of the 16 isolates was confirmed twice by spraying, until runoff, ten tomato seedlings (cv. Heinz 6691) at the four-true-leaf stage with each bacterial suspension adjusted to $10^{8} \mathrm{CFU} \mathrm{ml}^{-1}$. Six days postinoculation, small dark brown spots similar to those observed in naturally infected plants developed on leaves of all inoculated plants (Fig. 4). Negative control plants sprayed with either $P$. syringae pv. syringae (CFBP1392, isolated from Syringa vulgaris) or sterile distilled water were symptomless. Bacteria re-isolated from the necrotic lesions showed the same cultural and biochemical characteristics as those used for inoculation, thus fulfilling Koch's postulates.

The 16S rRNA gene of five representative isolates (recovered from diseased plants from the Teboulba region) was amplified by PCR using universal primers as described by Manceau \& Horvais (1997). Amplicons of the five isolates were sequenced and the sequences obtained were $99 \%$ identical to the 16S rRNA gene sequence from Pseudomonas syringae pv. tomato (GenBank Accession No. MH979333:MH979337), the causal agent of bacterial speck of tomato. Pathogen identity was confirmed using pathovar-specific primers (MM5F and MM5R) from the hrpZPst gene (Zaccardelli et al., 2005), and an amplicon of 532 bp was obtained for all 16 isolates.

Infected seeds and/or transplants were the most likely source of introduction of this pathogen to Tunisia. To the best of our knowledge, this is the first report of the occurrence of bacterial speck of tomato in Tunisia. A large-scale survey should be undertaken to determine the geographical distribution of this new disease and to determine which races of $P$. syringae pv. tomato are present.

\section{Acknowledgements}

The authors thank Ms Mouna Gueddes for her technical assistance. This work was funded by IRESA through the funding attributed to the multidisciplinary and the multi-institutional project CleProD.

\section{References}

Manceau C, Horvais A, 1997. Assessment of genetic diversity among strains of Pseudomonas syringae by PCR-restriction fragment length polymorphism analysis of rRNA operons with special emphasis on $P$. syringae pv. tomato. Applied and Environmental Microbiology 63, 498-505.

Zaccardelli M, Spasiano A, Bazzi C, Merighi M, 2005. Identification and in planta detection of Pseudomonas syringae pv. tomato using PCR amplification of hrpZPst. European Journal of Plant Pathology 111, 85-90. http://dx.doi.org/10.1007/s10658-004-2734-7

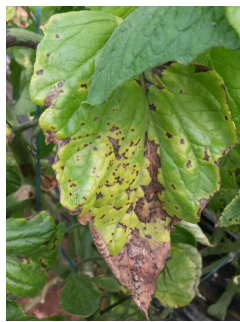

Figure 1

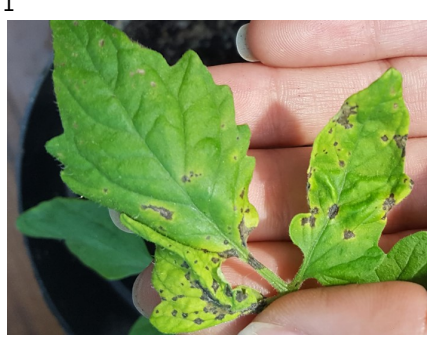

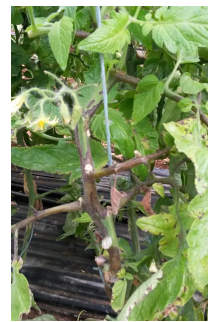

Figure 2

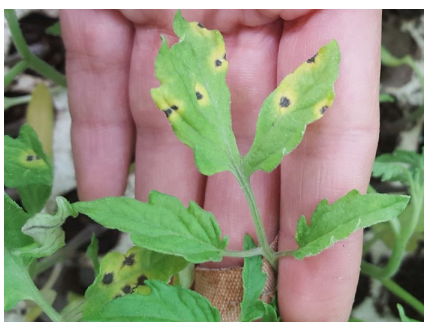

Figure 3

Figure 4

To cite this report: Mensi I, Jabnoun-Khiareddine $\mathrm{H}$, Zarrougui NE, Ben Zahra H, Cesbron S, Jacques MA, Daami-Remadi M, 2018. First report of tomato bacterial speck caused by Pseudomonas syringae pv. tomato in Tunisia. New Disease Reports $\mathbf{3 8}, 21$. http://dx.doi.org/10.5197/j.2044-0588.2018.038.021 